\title{
Designing Guidelines for Smart City Collaboration Tools
}

\author{
Anouk van Twist \\ School of Creative Technology, \\ Saxion University of Applied \\ Sciences, The Netherlands \\ a.e.vantwist@saxion.nl \\ Erna Ruijer \\ School of Governance, Utrecht \\ University, The Netherlands \\ h.j.m.ruijer@uu.nl
}

\author{
Mark Melenhorst \\ School of Creative Technology, \\ Saxion University of Applied \\ Sciences, The Netherlands \\ m.s.melenhorst@saxion.nl \\ Meike Kolk \\ School of Creative Technology, \\ Saxion University of Applied \\ Sciences, The Netherlands \\ m.j.kolk@saxion.nl
}

\author{
Mettina Veenstra \\ School of Creative Technology, \\ Saxion University of Applied \\ Sciences, The Netherlands \\ m.j.a.veenstra@saxion.nl \\ Albert Meijer \\ School of Governance, Utrecht \\ University, The Netherlands \\ a.j.meijer@uu.nl
}

\begin{abstract}
Cities around the world have started pilots to experiment with Information and Communication Technologies (ICTs) to tackle urban problems, optimize city services and enhance the quality of life for citizens. At the moment, many smart city pilots have difficulty scaling up beyond the pilot stage. Effective collaboration between quadruple-helix partners in the smart city is both crucial and challenging for promoting the development, implementation, and scaling-up of smart city pilots. However, professionals in the smart city field lack easy-to-use tools to resolve smart collaborative governance challenges. To bridge this gap, this paper will use a Design Science Research (DSR) methodology to develop generic high-level guidelines for smart collaborative governance tools in the smart city context. These generic high-level guidelines also include guidelines that help to resolve dilemmas in the design of collaboration tools regarding their desired outcomes, complexity, and scope.
\end{abstract}

\section{Introduction}

The smart city concept has attracted much attention among policymakers and urban developers. Recent reviews of smart city literature $[1,2,3]$ emphasize the importance of (quadruple-helix) collaborations to develop, implement and upscale smart city pilots. However, public professionals encounter many challenges collaborating with colleagues, businesses, research institutes and citizens $[1,4,5]$. As a result, many smart city pilots have difficulties with scaling, and this is perceived as a major problem since the intended benefits of these smart city pilots remain limited $[4,6$, 7].

Practical tools could help professionals in the smart city field to tackle smart collaborative governance challenges in scaling up smart city pilots $[8,9]$. Despite the value for practice, little attention has been paid to the conceptualization of tools and few practically applicable tools have been developed to support professionals in smart city practice $[10,11]$.

Therefore, this research intends to develop design guidelines for smart collaborative governance tools (hereafter: collaboration tools) by means of a DSR methodology to stimulate the development of practical tools for professionals in the smart city domain.

This paper is structured as follows. The next section clarifies and refines the notions of 'smart city', 'smart collaborative governance' and 'tools'. Subsequently, Hevner's [12, 13] design science methodology is described to illustrate the methodology used. The following section introduces generic high-level guidelines for collaboration tools based on identified requirements and dilemmas. The final section discusses the findings, draws conclusions, and derives some recommendations for future research.

\section{Theory}

\subsection{Smart Collaborative Governance}

A wide variety of definitions exists for the term smart city, and a generally accepted definition is still lacking $[14,15,16]$. Many of these definitions emphasize the importance of strong collaboration between public managers, citizens, businesses, and research institutes to develop and implement smart city 
pilots $[1,4,6,7]$. For example, according to Van Winden \& Van den Buuse [4, pp. 68]: "Smart city projects are [..] arenas where different urban stakeholders (public, private and civic) engage in coalitions and innovate together" to develop smart city projects, while Meijer \& Bolívar [3, pp. 398] also give collaboration a central potion within their definition: "the ability to attract human capital and to mobilize this human capital in collaborations between the various (organized and individual) actors through the use of information and communication technologies".

Collaboration among a broad range of stakeholders has been a longstanding topic in research on ICT service innovation, living labs, and public administration. More recently, this topic has gained attention in smart city research.

The collaborative governance literature focuses on processes and structures of public policy decisionmaking and management, that engage people constructively across the boundaries of organizations to carry out a public purpose [17] (pp. 2). In addition, collaboration can take shape through the quadruplehelix relationship between government, residents, research institutions and private companies [55]. In this strand of literature $[17,18,19,20]$ the following collaborative governance components are identified: (1) system (e.g. rules and regulation, antecedents such as prehistory of conflict and cooperation, existing relationships or networks, resource scarcity and interdependency), (2) process (e.g. trust, mutual understanding, commitment, communication, leadership and legitimacy), (3) structure (e.g. formal and informal rules, roles and responsibilities, and decision making) and (4) outcomes (e.g. intended objective, learning and public value).

Smart governance authors address the impact of ICT on city governance that enable new forms of collaboration to address societal issues. In this strand of literature authors make a distinction between (1) context components (e.g., policy domain, trust in government, the availability of technology and technical skills, and the social / political / economic / institutional environment), (2) strategic components (e.g., an integrated vision), (3) smart governance arrangements (e.g. stakeholders, organization structure, processes, participation, roles and responsibilities, legislation and policies) and (4) outcomes (first, second and third order outcomes) [21, 22, 23].

A comparison of collaborative governance and smart governance components literature demonstrates differences in focus. The smart governance literature is mainly focused on the structure and organization of the partnership with much attention for the stakeholders, the coordination structures, the distribution of roles and smart governance 'processes' (participation, communication and the decision-making process). In contrast, collaborative governance frameworks also identify more 'soft' components that can influence collaborations $[17,18,19,20]$, such as e.g., trust, shared understanding, leadership, and commitment. We will combine both research fields to get a comprehensive understanding of smart collaborative governance.

\subsection{Smart City Collaboration Tools}

Collaboration tools may offer support to professionals aiming to realize smart collaborative governance $[8,9]$. In spite of the prevalence of such tools in smart city practice, little attention has been paid in the literature to the conceptualization and the design process of practically applicable collaboration tools. In this paper, collaboration tools refer to tools for initiating, supporting, and evaluating smart collaborative governance. This includes offline and online tools that can focus on different or all aspects of smart collaborative governance with the aim to support the development, implementation and scaling-up of smart city pilots.

This paper argues that smart city professionals can benefit from practical collaboration tools that are designed in a systematic fashion adopting a DSR approach. As a first step, this paper develops generic high-level guidelines that can support the development of practical collaboration tools in the smart city context.

\section{Design Science Methodology Overview}

Attention to design in public administration has increased significantly [24]. DSR could be promising for the field of public administration because DSR is supposed to result in relevant and actionable insights regarding wicked social problems, contribute to the needs and wishes of the 'users' (e.g., local public administrators), and DSR could foster creativity for developing innovative solutions $[24,25,26]$. While design science is a relatively common approach in the information systems domain, the design perspective is still a niche approach in Public Policy and Administration research, despite the possible contributions that design science can make $[25,26]$.

In this paper, the widely used design science methodology of Hevner [12, 13], developed for design research on information systems, was applied with the purpose of developing guidelines for collaboration tools to support the development and scaling-up of smart city pilots. This method consists of three overlapping cycles - relevance, rigor, design cycle - that ultimately extend the knowledge base about the potential of practical tools to resolve challenges in smart collaborative governance. 
The relevance cycle approach fuses the approach proposed by Hevner [13] and Bosua et al. [27], with the purpose of adapting the approach to the context of tool development for smart collaborative governance in the smart city domain. Firstly, a multiple case study approach was adopted to assess smart collaborative governance challenges in the smart city domain of practice. Secondly, a qualitative gap analysis was performed to assess existing collaboration tools in relation to the challenges professionals encounter in the smart city domain. Thirdly, a requirements analysis for smart collaboration tools was conducted. Generic high-

Relevance cycle level guidelines for smart city tools constitute the final contribution of this paper to the knowledge base as part of the rigor cycle. The generic guidelines and detailed requirements serve as the starting point for the design cycle in which new tools are developed and existing tools (found in step 2) will be adapted.

The data collection and analysis for these three steps of the relevance cycle will be sequentially explained below. See Figure 1 for an overview of the three steps, the focus of the research, and the empirical data collection that consisted of interviews, workshops, expert sessions, and literature reviews.

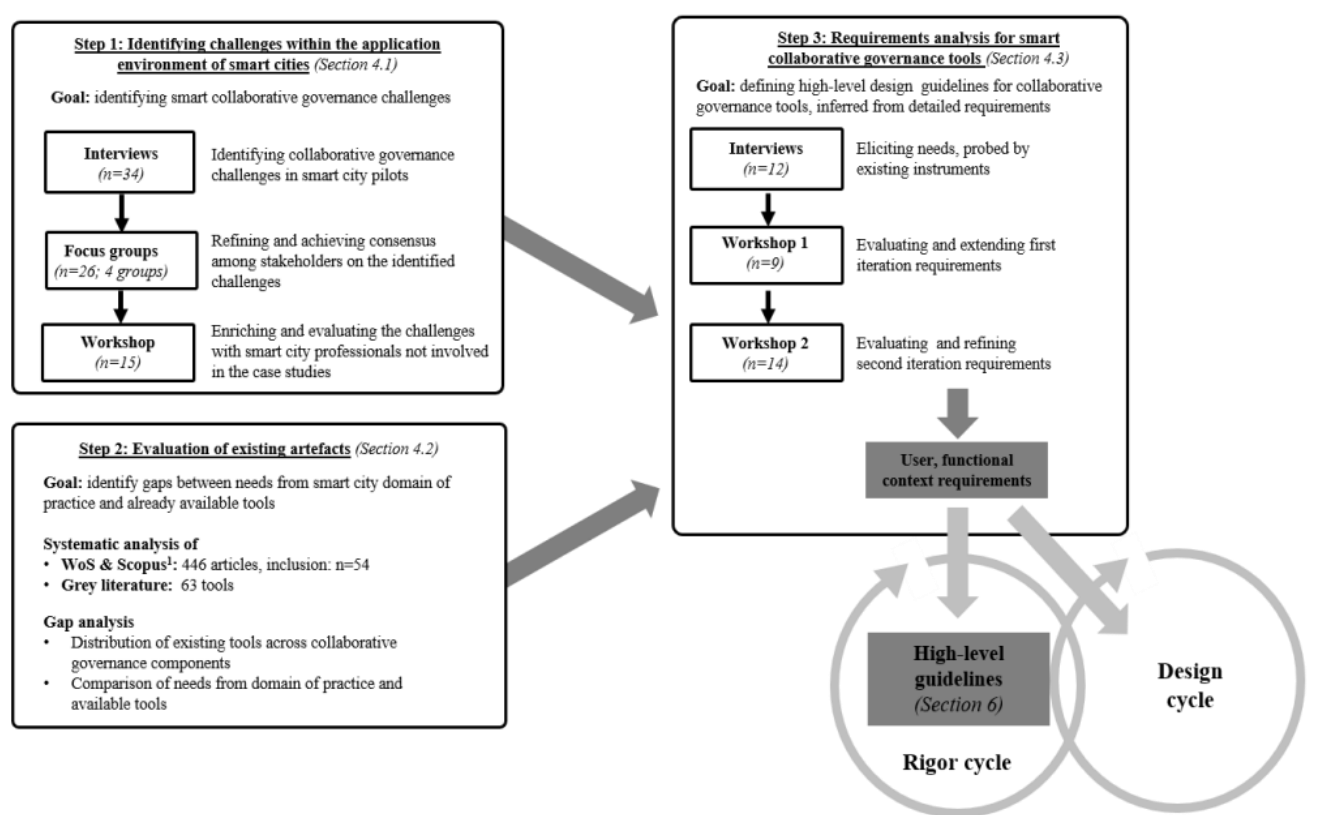

Figure 1. Relevance cycle: Three-step approach and focus of this study (Adapted from [13])

\section{Implementation of Methodology in Smart City Domain of Practice}

\subsection{Step 1: Identifying challenges in smart city domain of practice}

4.1.1. Method. To identify opportunities and challenges in the application environment [13], a multiple case study was conducted to get an in-depth and nuanced understanding of smart collaborative governance challenges that professionals encounter during the implementation and scaling-up of smart city pilots. In the multiple case study research, four different cases in four different cities in the Netherlands were compared against each other to discover differences and similarities between the cases (Table 1) and increasing the methodological accuracy of the study [28]. The empirical data for the case studies were collected between May 2020 and February 2021.
Table 1. Description of case studies

\begin{tabular}{l|l} 
City & Smart City application \\
\hline Amersfoort & $\begin{array}{l}\text { Pedestrian counting tool to evaluate the quality of } \\
\text { the urban environment. }\end{array}$ \\
\hline Rotterdam & $\begin{array}{l}\text { A connective energy network tool to provide an } \\
\text { integrated system (e.g., EV charging, 5G, } \\
\text { environmental sensors). }\end{array}$ \\
\hline Zwolle & $\begin{array}{l}\text { Environmental sensor network to gain insight into } \\
\text { the local climate. }\end{array}$ \\
\hline Enschede & $\begin{array}{l}\text { Smart mobility application to promote healthier } \\
\text { and greener travel behavior }\end{array}$
\end{tabular}

34 semi-structured interviews were held with various stakeholders to identify smart collaborative challenges that affected the development or execution of a specific smart city project. Thereafter, focus groups were organized with all the stakeholders involved in each of the case studies to achieve consensus on the identified challenges among stakeholders and to get a 
more in-depth understanding of these challenges. Lastly, a workshop was conducted to confront the first results of the case studies against the practical experience and expertise of a broader group of smart city experts not involved in the cases.

The data were transcribed and coded according to the grounded theory system [29], using ATLAS.TI. The components of the theoretical framework for smart collaborative governance (see 2.2) were used as the starting point of the coding tree. Subsequently, the coding tree was further refined by identifying additional themes that emerged from the codes identified [30].

4.1.2. Results. Five main themes of smart collaborative governance challenges in the smart city context emerged from the four case studies. These challenges are described below in Table 2 .

\section{Table 2. Overview of smart collaborative governance challenges}

\begin{tabular}{|l|l|l|}
\hline Theme & $\begin{array}{l}\text { No. of } \\
\text { codes }\end{array}$ & $\begin{array}{l}\text { Description smart collaborative } \\
\text { governance challenge }\end{array}$ \\
\hline Interests & 26 & $\begin{array}{l}\text { Competing interests between } \\
\text { quadruple-helix partners, and } \\
\text { within organizations. }\end{array}$ \\
\hline $\begin{array}{l}\text { Political } \\
\text { Support }\end{array}$ & 17 & $\begin{array}{l}\text { Lack of political support because } \\
\text { of interest, affinity and / or } \\
\text { knowledge of individual } \\
\text { counselors with the smart city } \\
\text { concept. }\end{array}$ \\
\hline Outcomes & 15 & $\begin{array}{l}\text { The outcomes of smart city pilots } \\
\text { are difficult to show, because } \\
\text { objectives are not clearly defined } \\
\text { in advance, and it is difficult to } \\
\text { quantify social benefits. }\end{array}$ \\
\hline $\begin{array}{l}\text { Privacy } \\
\text { Legislation }\end{array}$ & 14 & $\begin{array}{l}\text { Privacy legislation hampers the } \\
\text { development and execution of } \\
\text { smart city pilots. }\end{array}$ \\
\hline $\begin{array}{l}\text { Citizen } \\
\text { Participation }\end{array}$ & 12 & $\begin{array}{l}\text { Citizen participation and } \\
\text { (enduring) involvement } \\
\text { is difficult to achieve, due to the } \\
\text { complexity of the smart city } \\
\text { concept and the extent to which } \\
\text { citizens want to participate in } \\
\text { public policies. }\end{array}$ \\
\hline
\end{tabular}

The case studies provided insights into the main challenges for collaboration between quadruple-helix partners in the context of smart city pilots. Following, we systematically identified existing collaboration tools and evaluated whether these tools sufficiently address practitioners' challenges.

\subsection{Step 2: Evaluation of Existing Artefacts}

4.2.1. Method. To evaluate the existing artefacts (in our case: tools) [13], we used a systematic approach to identify existing smart collaborative governance tools in the academic and grey literature. This subsection summarizes the methodology and the main findings, while the comprehensive description of methodology and results can be found in Ruijer et al. [11, 12].

The academic literature review was conducted based on the 'Preferred Reporting Items for Systematic Reviews and Meta-Analyses' (PRISMA) [31]. A search query was performed on the electronic databases of Scopus and Web of Science (WoS). The databases were searched for keywords "smart city" and "collaborative governance", "collaboration", "partnership" in combination with words such as "instrument", "tool", "frame", "format", "method" or "lessons-learned"1. We searched for primary articles published in English up to September 2020. The screening of all articles led to the inclusion of 54 studies. The flow diagram for selecting the records is presented in Figure 2.

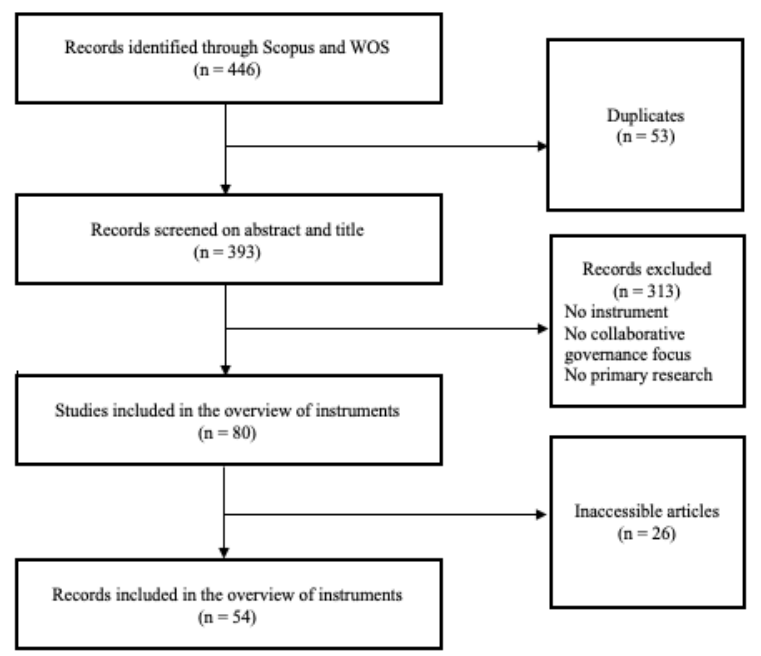

Figure 2. Flow diagram

In addition to the academic literature, we searched for grey literature. In line with Hopewell et al. [32], we define grey literature as "that which is produced on all levels of government, academia, business and industry in print and electronic formats, but which is not controlled by commercial publishers" (pp. 49). We

\footnotetext{
1 "Smart City" AND ("Collaborative Governance" OR "Collaboration" Or "Partnership" OR "Cross-sector collaboration" OR "Public-private collaboration" OR "Public-private partnership" OR "triple helix collaboration" OR "quadruple helixcollaboration") AND ("Tool*" OR "Template*" OR "Instrument*" OR "Gadget*" OR "Device*" OR "apparatus*" OR "model*" OR "Format *" OR "Frame*" OR "Checklist*" OR "Method*" OR "Lessons learn*" Or "Lessons drawn" OR "Best practices" OR "principle*” OR "guideline*” OR “canvas")
} 
decided to follow the search approach based on hand searching and contacting specialists to find grey literature [33]. Therefore, we first selected frontrunner countries, based on the scientific literature and on two international smart city indexes (IMD smart city Index and IESE Cities in Motion Index), and selected countries that are geographically spread around the world. Within these countries, we selected frontrunner cities. Because this study takes place in a Dutch context, we also specifically selected Dutch cities. This led to the following list of countries and cities: USA (New York, Los Angeles, Chicago); UK (London, Glasgow, Cardiff); Nordic European Countries (Helsinki, Copenhagen, Berlin); Asian Countries (Seoul, Singapore, Hongkong); Netherlands (Amsterdam, Rotterdam, The Hague, Eindhoven).

Second, within each city we hand searched for Flagship initiatives and analyzed if and how these related to collaborative governance. Following, we searched if tools were used during the collaboration of the Flagship initiative. Third, we used both Google Scholar and Google with the academic key terms thereby adding the name of the city and analyzed the first 10 pages found. Finally, within each of these countries we approached an expert in the smart city field and asked whether they had information about tools. This led to four interviews with experts in the field and three additional documents were forwarded to us via email.

4.2.2. Results. Based on the results of the academic and grey literature we created a list of in total 117 tools: 54 based on the academic literature, 63 tools based on the grey literature. The tools found were intended to support quadruple-helix partners in the collaborative exploring, ideating, testing, and scaling phases of innovative collaborations. The broad range of tools included online (e.g., evaluation and e-participation software) and offline tools (e.g., templates, checklists).

As a next step, the tools found in the academic and grey literature were compared against the smart city challenges identified in the multiple case study research. See Table 3 for an overview of identified tools for the discussed challenges. For more (information about the) tools and the selection of tools see $[10,11]$

Table 3. Overview of identified tools

\begin{tabular}{|c|c|c|}
\hline Challenge & Available tools & Description of the tools \\
\hline \multirow{2}{*}{$\begin{array}{l}\text { Interests } \\
\text { ( } 2 \text { tools found) }\end{array}$} & Value Mapping Tool [34] & Identifying and aligning values among stakeholders. \\
\hline & Theater Workshop [35] & $\begin{array}{l}\text { Identifying different 'stakes' among stakeholders and confronting product and } \\
\text { prospective users. }\end{array}$ \\
\hline \multirow{2}{*}{$\begin{array}{l}\text { Political } \\
\text { support } \\
\text { (2 tools found) }\end{array}$} & Causes Diagram [34] & Clarify priorities by breaking down complex issues. \\
\hline & The Digital Advisor [36] & $\begin{array}{l}\text { Supports council members in imaging, judgement, decision-making regarding } \\
\text { digitization and data. }\end{array}$ \\
\hline \multirow[t]{5}{*}{$\begin{array}{l}\text { Outcomes } \\
\text { (5 tools found) }\end{array}$} & $\begin{array}{l}\text { CITYkeys performance measurement } \\
\text { Framework [37] }\end{array}$ & A (software) tool for assessing smart city projects and performance. \\
\hline & The Impact path [38] & An entrepreneur's guide to growth in social impact measurement. \\
\hline & $\begin{array}{l}\text { An overview of instruments to measure } \\
\text { the effect of your approach [39] }\end{array}$ & Overview of different tools that can be used to measure outcomes. \\
\hline & InstrumentWijzer [40] & Overview of different tools that can be used to measure outcomes. \\
\hline & Business Model Metrics [41] & $\begin{array}{l}\text { The tool helps to monitor performance and select measurable performance } \\
\text { indicators. }\end{array}$ \\
\hline \multirow{4}{*}{$\begin{array}{l}\text { Privacy } \\
\text { legislation } \\
\text { (4 tools found) }\end{array}$} & Solutions for privacy in smart city [42] & $\begin{array}{l}\text { Article about privacy regarding applications, technologies, challenges, and } \\
\text { solutions in the smart city. }\end{array}$ \\
\hline & Data Ethics Decision Aid [43] & $\begin{array}{l}\text { DEDA helps data analysts, project managers and policy makers to recognize } \\
\text { ethical issues in data projects, data management and data policies. }\end{array}$ \\
\hline & Checklist Data Sharing [44] & $\begin{array}{l}\text { The checklist offers guidance to organizations that want to share data with } \\
\text { each other in a responsible way to tackle social issues. }\end{array}$ \\
\hline & Data Sharing Toolkit [45] & Toolkit to help organizations share city data. \\
\hline \multirow{5}{*}{$\begin{array}{l}\text { Participation } \\
\text { (5 tools found) }\end{array}$} & Smart Nation Ambassador [46] & Ambassador program in which digital-skilled citizens help other citizens. \\
\hline & Citizen sensing a toolkit [47] & Tools to enable awareness and engagement regarding sensing. \\
\hline & Omgevingscanvas [48] & $\begin{array}{l}\text { Method for making, enriching, and justifying spatial plans by civil servants, } \\
\text { entrepreneurs, and citizens. }\end{array}$ \\
\hline & Citizens' Assembly [49] & Evaluation report about the citizens' Assembly in Wales. \\
\hline & Digital Twin [50] & Urban digital twins to facilitate citizen engagement in the smart city. \\
\hline
\end{tabular}

Further inspection of the tools by smart city professionals revealed that many tools consisted of abstract ideas (e.g., Theater workshop; Smart Nation Ambassador; Citizens' Assembly) or overwhelming information (e.g., The impact path; Data Ethics Decision Aid) and were therefore not immediately applicable in practice without adjustments $[10,11]$. Additionally, the tools were not helpful for all the 
identified smart collaborative governance components and challenges. Thus, despite the broad range of tools found, not all tools offered professionals in the smart city field adequate easy-to-use tools to resolve the smart collaborative governance challenges.

To conclude, closer examination of practitioners' challenges and the tools provided an empirical basis for adaptations of existing collaboration tools and for the development of new tools. In the next section, we will formulate requirements for tools that can provide input for the formulation of guidelines and the development of collaboration tools.

\subsection{Step 3: Requirements for Smart Collaborative Governance Tools}

4.3.1. Method. A requirement analysis [13] was conducted based on interviews with 12 smart city professionals. The requirements analysis provided the empirical basis for the definition of high-level design guidelines, as the final addition of this paper to the knowledge base on collaboration tools.

For these semi-structured interviews, respondents from municipalities, companies and research institutes that participated in steps 1 and 2 were asked to participate. These respondents were selected because of their involvement in the development or implementation of the smart city pilots in the four case studies. The aim of the semi-structured interview was to (1) evaluate whether the identified tools offer support to resolve smart collaborative governance challenges identified in a case study (2) and to retrieve generic requirements for tools. To test this, two tools were selected and presented to each respondent. The tools were selected to represent (1) a variety of smart collaborative governance challenges (2) and a variety of types of tools (e.g., ICTenabled frameworks, guidelines, templates, workshops). See Table 3 above to get an impression of the presented tools.

In addition to the interviews, two requirement workshops were conducted. The aim of the first preliminary requirements workshop was to identify requirements for collaboration tools by showing participants possible collaboration tools. The aim of the second workshop was to validate the complete list of requirements that was developed with data from interviews and the first preliminary workshop. In addition, participants had the possibility to add new requirements to the list.

For the data analysis aimed at formulating requirements, we developed a template. In this template, we systematically filled in the type of requirement [51], the requirement description, the quadruple-helix actor [55], the foundation of the requirement in interviews or workshops, and the version history of the requirement.
Requirements were subdivided into three categories: user, functional, and context [51] (pp. 735) (Table 4). In addition, requirements were specified following the well-known user story template [52]: as [actor], I want to [need], so that [goal].

\section{Table 4. Description of requirements categories [51]}

\begin{tabular}{l|l} 
& Description \\
\hline User & $\begin{array}{l}\text { Demands of the future users of the artefact, } \\
\text { within the frame that is defined by the goals } \\
{[G]}\end{array}$ \\
Functional & $\begin{array}{l}\text { The functions that the artefact should fulfil or } \\
\text { enable to perform once it is realized, within } \\
\text { the frame that is defined by the goals [G] } \\
\text { Prerequisites set by the political, economic, } \\
\text { juridical and or social environment }\end{array}$
\end{tabular}

4.3.2. Results. The research findings (interviews and focus groups with 34 smart city professionals) led to the specification and iterative refinement of 21 requirements. More precisely, the final requirements included 8 users, 12 functional and 1 context requirement (see Table 5 for an impression of the requirements and see [11] for a complete overview of the requirements).

The requirements describe what professionals claim to be important when using collaboration tools, such as: tools should contribute to a high-impact portion of the collaboration challenges, and tools should be transparent about the trade-off between effort and impact. Further analysis of the requirements and the underlying workshop and interview data revealed contradictions as smart city professionals prioritize different underlying goals and have different expectations about the outcomes, complexity, and scope of collaboration tools. From these contradictory requirements, three dilemmas were identified.

Dilemma 1: The outcomes of a tool should be 'predictable' versus 'innovative'

On the one hand, requirements indicate that it is important for some smart city professionals to foresee the outcomes and benefits of using a tool in advance so that the ratio between costs and revenues and the contribution of the tool to the smart collaborative governance challenge can be estimated. Besides, the possible benefits need to be communicated to the collaboration partners to enhance the support for the use of the tool $(\mathrm{N}=15)$. On the other hand, other experts question the possibility of estimating what the outcomes and costs of a tool might be in advance. For example, the benefits of a tool are also very dependent on the persons using the tool, the way the tool is used and the (underlying) collaboration challenges. In addition, the costs of using a tool may decrease if partners have more 
experience using the tools, or costs may increase because of the associated risks in a particular context. Nevertheless, according to this group of smart city experts and professionals, it is important that the quest for predictable outcomes and proven tools does not prevent the use of new and innovative tools that still need to be tested in real life to understand their possible outcomes $(\mathrm{N}=3)$.

Dilemma 2: The complexity of a tool should be: 'simple' versus 'informed'

Requirements indicate that smart city professionals want to use simple and manageable tools that clearly indicate what to do so that little time is needed to understand, explain, and use the tool. Smart city professionals argue that complex tools can sometimes seem overwhelming and could deter the use of a tool. Therefore, they indicate that tools should give the user as little discretion as possible to minimize efforts $(\mathrm{N}=14)$. However, other experts indicated to prefer complete, comprehensive and 'academically informed' tools to tackle smart collaborative governance challenges. These tools might not always be easy to understand but could ensure that smart collaborative governance challenges are addressed in an informed and complete manner $(\mathrm{N}=4)$.
Dilemma 3: The scope of a tool should be: restricted versus comprehensive

Requirements indicate that some experts assume that tools should help to tackle manageable subproblems of a smart collaborative governance challenge. These experts argue that smart collaborative governance challenges are big and compelling and that tools should have a limited scope, to resolve a small, manageable part of a smart collaborative governance challenge $(\mathrm{N}=2)$. On the other hand, other smart city professionals $(\mathrm{N}=4)$ prefer tools with a broader scope to avoid losing focus on the smart collaborative governance challenge at large.

\section{Specification of Guidelines}

The requirements analysis process bridges the gap between the relevance cycle and the design cycle [13]. To consolidate the findings of the relevant cycle, highlevel design requirements were derived as a metaartefact that extends the knowledge base on smart collaborative governance tools. A thematic analysis was used for this purpose, resulting in 9 high-level guidelines [53] based on the requirements (R) and dilemmas (D). The generic high-level guidelines and some examples of requirements are displayed in Table 5 below.

Table 5. Overview of guidelines

\begin{tabular}{|c|c|c|c|}
\hline Guidelines & Description & $\begin{array}{l}\text { No. of } \\
\text { related } \\
\text { req.'s }\end{array}$ & Exemplary related requirement \\
\hline $\begin{array}{l}\text { Collaboration tools should } \\
\text { contribute to a high-impact } \\
\text { portion of the collaboration } \\
\text { challenge. }(\mathbf{R})^{*}\end{array}$ & $\begin{array}{l}\text { Tools should resolve a portion of a smart } \\
\text { collaborative governance challenge that has } \\
\text { potential impact on the implementation, execution } \\
\text { or scaling of a smart city pilot, which can be } \\
\text { resolved by usage of the tool. }\end{array}$ & 4 & $\begin{array}{l}\text { As a facilitator, I want tools that enable } \\
\text { an open dialogue aimed at expressing } \\
\text { everyone's interests within the project, } \\
\text { so that challenges in the collaboration } \\
\text { can be resolved. }\end{array}$ \\
\hline $\begin{array}{l}\text { Collaboration tools should be } \\
\text { transparent about the } \\
\text { balance between their } \\
\text { contribution to the } \\
\text { collaboration challenge and } \\
\text { the effort the stakeholders of } \\
\text { the tool should invest. (R) }\end{array}$ & $\begin{array}{l}\text { Time investment of both stakeholders and (if } \\
\text { applicable) a facilitator should be aligned and in } \\
\text { balance with the intended contribution to the smart } \\
\text { collaborative governance challenge. Tools should } \\
\text { be transparent about this trade-off. }\end{array}$ & 4 & $\begin{array}{l}\text { As a stakeholder, I want for myself and } \\
\text { for stakeholders that the time investment } \\
\text { for the use of the tool is proportional to } \\
\text { the output, so that the stakeholders are } \\
\text { prepared to use the tool }\end{array}$ \\
\hline $\begin{array}{l}\text { Collaboration tools should } \\
\text { help to build support for } \\
\text { their usage by the } \\
\text { stakeholders. (R) }\end{array}$ & $\begin{array}{l}\text { Stakeholders must be convinced of the contribution } \\
\text { the usage of a tool can make to the collaboration } \\
\text { process between stakeholders. The design of the } \\
\text { tools should encourage support among } \\
\text { stakeholders for its usage by transparently } \\
\text { conveying its added value. }\end{array}$ & 4 & $\begin{array}{l}\text { As a stakeholder, I want to use tools } \\
\text { with a clear purpose and usefulness, so } \\
\text { that stakeholders support the use of the } \\
\text { tool. }\end{array}$ \\
\hline $\begin{array}{l}\text { Collaboration tools should } \\
\text { allow for their results to be } \\
\text { integrated in the } \\
\text { collaboration process. }(R)\end{array}$ & $\begin{array}{l}\text { Tools must ensure that before, during, and after the } \\
\text { usage of a tool the results can be integrated into } \\
\text { the process of collaboration between stakeholders } \\
\text { and can have long lasting effects. }\end{array}$ & 3 & $\begin{array}{l}\text { As a stakeholder, I want to be able to } \\
\text { use a tool multiple times during the } \\
\text { collaboration process, so that the tool } \\
\text { can contribute to the collaboration } \\
\text { throughout the process. }\end{array}$ \\
\hline
\end{tabular}




\begin{tabular}{|c|c|c|c|}
\hline $\begin{array}{l}\text { Collaboration tools should be } \\
\text { adaptable to specific needs } \\
\text { and/or the local context. (R) }\end{array}$ & $\begin{array}{l}\text { The objective is to resolve a portion of the } \\
\text { collaboration process with tools that are adaptable } \\
\text { to specific needs and/or the local context, without } \\
\text { imposing a rigid format on stakeholders. }\end{array}$ & 2 & $\begin{array}{l}\text { As a stakeholder, I want that the tool can } \\
\text { be flexibly deployed, so that the tool can } \\
\text { be adapted to the local situation and } \\
\text { context. }\end{array}$ \\
\hline $\begin{array}{l}\text { Decision support tools should } \\
\text { help users to decide what } \\
\text { collaboration tool(s) to use } \\
\text { and to help justify these } \\
\text { choices. (R) }\end{array}$ & $\begin{array}{l}\text { Stakeholders need support in choosing a tool as } \\
\text { well as justifying that choice, given the } \\
\text { stakeholders and a particular smart collaborative } \\
\text { governance challenge. }\end{array}$ & 1 & $\begin{array}{l}\text { As a stakeholder, I want a toolbox that } \\
\text { supports me in making decisions about } \\
\text { the choice for a particular tool, so that I } \\
\text { can easily choose a tool and substantiate } \\
\text { the choice for it. }\end{array}$ \\
\hline $\begin{array}{l}\text { Collaboration tools should } \\
\text { allow for evaluation of the } \\
\text { desired outcomes in the } \\
\text { collaboration process. (D) }\end{array}$ & $\begin{array}{l}\text { Stakeholders must be convinced of the contribution } \\
\text { the usage of a tool can make to the collaboration } \\
\text { process between stakeholders. The incorporation of } \\
\text { evaluation moments should encourage support } \\
\text { among stakeholders for its effectiveness by } \\
\text { transparently evaluating its added value. }\end{array}$ & 1 & $\begin{array}{l}\text { As a stakeholder, I want to make a go / } \\
\text { no-go decision about the use of a tool at } \\
\text { an unambiguously identifiable moment } \\
\text { in the process, so that the desired } \\
\text { outcome remains monitored during the } \\
\text { process. }\end{array}$ \\
\hline $\begin{array}{l}\text { Collaboration tools should } \\
\text { give users the possibility to } \\
\text { decide about the appropriate } \\
\text { complexity level of the tool. } \\
\text { (D) }\end{array}$ & $\begin{array}{l}\text { The objective is to resolve smart collaborative } \\
\text { governance challenges with tools that are } \\
\text { adaptable to the needs of the users, given the } \\
\text { stakeholder motivations and experience with } \\
\text { collaboration tools. }\end{array}$ & 1 & $\begin{array}{l}\text { As a stakeholder, I want to have the } \\
\text { freedom to choose between a simple and } \\
\text { an advanced tool, so that stakeholders } \\
\text { can select the appropriate level of } \\
\text { complexity of the tool. }\end{array}$ \\
\hline $\begin{array}{l}\text { Collaboration tools should } \\
\text { give users the possibility to } \\
\text { decide about the appropriate } \\
\text { scope of the tool. (D) }\end{array}$ & $\begin{array}{l}\text { The objective is to resolve smart collaborative } \\
\text { governance challenges with tools that are } \\
\text { adaptable to the needs of the users, given the } \\
\text { desired scope of a collaboration tool by } \\
\text { stakeholders }\end{array}$ & 1 & $\begin{array}{l}\text { As a stakeholder, I want to have the } \\
\text { freedom to let the scope of the } \\
\text { collaboration challenge that the tool } \\
\text { encompasses depend on the context, so } \\
\text { that myself or other stakeholders can } \\
\text { select the appropriate scoping level of } \\
\text { the tool. }\end{array}$ \\
\hline
\end{tabular}

*(R) Requirements, (D) Dilemmas

\section{Conclusion}

In this paper the widely used design science methodology of Hevner [12, 13], was used to develop generic high-level guidelines for collaboration tools to stimulate the development of practical smart collaborative governance tools to support quadruplehelix collaborations and the scaling of smart city projects. In this article, the relevance cycle was elaborated, in which a multiple case study approach was adopted to assess smart collaborative governance challenges, a gap analysis was performed to identify gaps in existing collaboration tools, and a requirements analysis was conducted to generate generic high-level guidelines.

The results have extended the knowledge base on smart collaborative governance in the following ways. First, the multiple case studies have increased the understanding of smart collaborative governance challenges from the perspective of different quadruplehelix stakeholders. Second, it was concluded that novel systematically designed collaboration tools are required, as existing collaborative governance tools are too limited in scope and abstract to have practical value for professionals in the smart city domain of practice. The requirements analysis has yielded detailed insights into the needs of these stakeholders regarding collaboration tools that can help to resolve the lack of suitable tools. The development of these tools is deemed important to tackle the smart collaborative governance challenges of the quadruple-helix partners in the smart city context.

Furthermore, the requirements process has yielded 21 requirements that formed the basis for the following generic high-level design guidelines: collaboration tools should contribute to a high-impact portion of collaboration challenges; should allow for their results to be integrated; should be transparent about the tradeoff between effort and impact; should help to build support for their use; and should be adaptable to local needs. Moreover, three dilemmas regarding the design of collaboration tools emerged in relation to the (1) desired outcomes, (2) complexity and (3) scope of collaboration tools. Therefore, additional generic highlevel guidelines have been formulated to deal with the dilemmas: collaboration tools should allow for evaluation of its desired outcomes and give users the possibility to decide about the appropriate complexity and scope of tools.

In addition, the guidelines have extended the knowledge base as part of the rigor cycle. This marks the transition to the second stage of this research project, the design cycle. The design cycle [13] will take the shape of action research [54]. Multiple case studies are foreseen, in which tools will iteratively be developed, used, and evaluated in terms of the contribution to the collaboration process. Therefore, reflecting on the current state of the requirements, it should be stressed that the requirements and guidelines reported here cannot be perceived as 'final'. First, in a design-science 
based project, requirements continue to evolve once artefacts (in our case: tools) are developed and evaluated in practice as part of the design cycle [13]. This will yield additional insights about the user needs, the desired characteristics, functions of the tools, and the opportunities and limitations the context imposes on the use of such tools. This may lead to modifications or additions across the categories of requirements (user, functional, context) [51]. Additionally, the sometimescontradictory requirements and corresponding guidelines could be modified based on insights gained while developing, using, and evaluating tools.

\section{References}

[1] R.W.S. Ruhlandt, "The governance of smart cities: A systematic literature review”, Cities, 81 (2018), pp. 1-23.

[2] T. Yigitcanlar, M. Kamruzzaman, L. Buys, G. Ioppolo, J. Sabatini-Marques, E.M. da Costa, and J.J. Yun, "Understanding 'smart cities': Intertwining development drivers with desired outcomes in a multidimensional framework", Cities, 81 (2018), pp. 145-160.

[3] A. Meijer and M. P. R. Bolívar, "Governing the smart city: a review of the literature on smart urban governance", Int. Rev. Adm. Sci., 82 (2016), pp. 392-408.

[4] W. van Winden and D. van den Buuse, "Smart city pilot projects: Exploring the dimensions and conditions of scaling up", Journal of Urban Technology, 24 (2017), pp. 51-72.

[5] P. Pierce and B. Andersson, B., "Challenges with smart cities initiatives-A municipal decision makers' perspective", 2017, pp. 2804-2813.

[6] M. van Lunenburg, K. Geuijen, and A. Meijer, "How and Why Do Social and Sustainable Initiatives Scale? A Systematic Review of the Literature on Social Entrepreneurship and Grassroots Innovation", VOLUNTAS: International Journal of Voluntary and Nonprofit Organizations, 31 (2020), pp. 1013-1024.

[7] E, G. Carayannis, and D. F. J. Campbell, "Mode 3" and "Quadruple Helix": Toward a 21st century fractal innovation ecosystem", International Journal of Technology Management, 46 (2009), pp. 201-234.

[8] T. A. Scott and C.W. Thomas, "Unpacking the collaborative toolbox: Why and when do public managers choose collaborative governance strategies?", Policy Studies Journal, 45 (2017), pp. 191-214.

[9] C. R. Prentice, M.T. Imperial, and J. L. Brudney, "Conceptualizing the collaborative toolbox: a dimensional approach to collaboration", The American Review of Public Administration, 49 (2019), pp. 792809.

[10] E. Ruijer, A. Van Twist, T. Haaker, T. Tartarin, N. Schuurman, M. Melenhorst, and A. Meijer, "Smart City Collaborative Tool Box: A systematic literature review of instruments that facilitate smart collaborative governance", EGPA, 2021.

[11] E. Ruijer, A. Van Twist, T. Haaker, T. Tartarin, N. Schuurman, and M. Melenhorst, "Deliverable 2.1: Overview of existing Instruments", https://www.samenwerkingstools.nl/wpcontent/uploads/2021/06/Deliverable-2.1.pdf, 2020.

[12] A. R. Hevner, S. T. March, J. Park, and S. Ram, "Design Science in Information Systems Research", (2004), pp. 75-105.

[13] A. R. Hevner, "A three-cyle view of design science research", Scandinavian Journal of Information systems", 19 (2007), pp. 87-92.

[14] T. Nam and T. A. Pardo, "Conceptualizing smart city with dimensions of technology, people, and institutions", In Proceedings of the 12th annual international digital government research conference: digital government innovation in challenging times, (2011), pp. 282-291.

[15] H. Chourabi, T. Nam, S. Walker, J. R. Gil-Garcia, S. Mellouli, S. Nahon, ..., and H. J. Scholl, "Understanding smart cities: An integrative framework", In 2012 45th Hawaii international conference on system sciences, IEEE, (2012), pp. 2289-2297.

[16] R. G. Hollands, "Will the real smart city please stand up? Intelligent, progressive or entrepreneurial?", City, 12 (2008), pp. 303-320.

[17] K, Emerson, T, Nabatchi, and S. Balogh, "An integrative framework for collaborative governance", Journal of public administration research and theory, 22 (2012), pp. $1-29$.

[18] J. M. Bryson, B. C. Crosby, and M. M. Stone, "The design and implementation of Cross-Sector collaborations: Propositions from the literature", Public Administration Review, 66 (2006), pp. 44-55.

[19] A. M. Thomson and J. L. Perry, "Collaboration processes: inside the black box," Public administration review, 66, (2006), pp. 20-32.

[20] C. Ansell and A. Gash, "Collaborative governance in theory and practice", Journal of public administration research and theory, 18 (2008), pp. 543-571.

[21] Y. Lin, "A comparison of selected Western and Chinese smart governance: The application of ICT in governmental management, participation and collaboration", Telecommunications policy, 42 (2018), pp. 800-809.

[22] Z. Tomor; A. Meijer; A. Michels, and S. Geertman, "Smart Governance for Sustainable Cities: Findings from a systematic Literature Review", Journal of Urban Technology, 26 (2019), pp. 3-27.

[23] M. P. R. Bolivar and A. J. Meijer, "Smart governance: Using a literature review and empirical analysis to build a research model," Social Science Computer Review, 34 (2016), pp. 673-692.

[24] M. Hermus, A. Van Buuren, and V. Bekkers, “Applying design in public administration: a literature review to explore the state of the art", Policy \& Politics, 48 (2020), pp. 21-48.

[25] A, G. L. Romme and A. Meijer, "Applying design science in public policy and administration research", Policy \& Politics, 48, (2020), pp. 149-165.

[26] G. F. Z. Santos, G. V. Koerich, and G. D. Alperstedt, "The contribution of design research in solving complex problems in the field of public administration", Revista de Administração Pública, 52, (2018), p.956-970.

[27] R. Bosua, R. Lederman, and K, Van Zyl, "Optimising healthcare ICT support for the care and management of 
elderly adults with mental illness in residential aged care facilities," Journal of Decision systems, 25 (2016), pp. 527-535.

[28] R.K. Yin, "Case study research: Design and methods", Thousand oaks, 2009.

[29] A. Strauss, and J. M. Corbin, "Grounded Theory in Practice", Thousand Oaks: SAGE Publications, 1997.

[30] A. Bryman, "Social Research methods," Oxford university press, 2016.

[31] A. Liberati, D. G. Altman, J. Tetzlaff, C. Mulrow, P. C. Gotzsch, J.P. Ioannidis, ....., and D. Moher, "The PRISMA statement for reporting systematic reviews and meta-analyses", Journal of clinical epidemiology, 62 (2009), pp. e1-e34.

[32] S. Hopewell, M. Clarke, and S. Mallet, "Grey literature and systematic reviews. Publication bias in metaanalysis: Prevention, assessment and adjustment", (2005), pp. 49-72.

[33] Q. Mahood, D. Van Eerd, and E. Irvin, "Searching for grey literature for systematic reviews: challenges and benefits", Research synthesis methods, 5 (2014), pp. 221 234.

[34] Nesta, "Value mapping Tool \& Causes Diagram", https://diytoolkit.org/tools/.

[35] M. Ryöppy, S. Ylirisku, P. Friis, J. Buur, "Postdramatic theatre in Smart City design", In Proceedings of the 20th International Academic Mindtrek Conference, (2016), pp. 462-465.

[36] Utrecht Data School, "The Digital Advisor," https://dataschool.nl/samenwerken/datawerkplaats/produ cten-en-tools/de-digitale-raadgever-concept/, 2021.

[37] Citykeys, "CITYkeys performance measurement Framework", http://www.citykeysproject.eu/citykeys/cities and regions/Performancemeasurement-framework

[38] Avance, Social Enterprise NL and Impact Centre Erasmus, "The Impact Path", https://impactpad.nl/english/.

[39] Movisie, "An overview of instruments to measure the effect of your approach", https://www.movisie.nl/sites/movisie.nl/files/publication -attachment/Zicht-op-effect $\% 20 \% 5$ BMOV-3296073$1.0 \% 5 \mathrm{D} . \mathrm{pdf}$.

[40] Movisie, "InstrumentWijzer", https://instrumentwijzer.nl.

[41] Saxion Hogeschool, "Business Model Metrics", https://businessmodellab.nl/en/tools/bedrijfsmodelmetrieken.

[42] D. Eckhoff, and I. Wagner, "Privacy in the Smart Cityapplications, technologies, challenges, and solutions", IEEE Communications Surveys \& Tutorials, 20 (2017), pp. 489-516.

[43] Utrecht Data School, "Data Ethics Decision Aid", https://dataschool.nl/en/deda/, 2017.

[44] Utrecht Data School, "Checklist Data Sharing", https://dataschool.nl/en/samenwerken/datawerkplaats/pr oducten-en-tools/samen-data-delen-concept/, 2020.

[45] Future Cities Catapult, "City Data Sharing Toolkit", https://1hir952z6ozmkc7ej3xlcfsc-wpengine.netdnassl.com/wp-content/uploads/2021/01/Tools-approachesand-resources-for-city-Governments-sharingnonpersonal-data.pdf, 2018.

[46] Government of Singapore, "Smart Nation Ambassador", https://www.smartnation.gov.sg/whats-new/be-a-smartnation-ambassador.

[47] Making Sense, "Citizen Sensing a toolkit", http://makingsense.eu/publication categories/toolkit/.

[48] Levelt, "Het omgevings canvas: Een hulpmiddel voor ambtenaren, ondernemers en burgers bij het maken, verrijken en verantwoorden van ruimtelijke plannen", https:/www.hva.nl/urban-technology/gedeeldecontent/contentgroep/rlink/omgevingscanvas/omgevingscanvas.html, 2020.

[49] Involve, "National Assembly for Whales - Citizens' Assembly", https://www.involve.org.uk/sites/default/files/field/attac hemnt/Citizens $\% 27 \% 20$ Assembly $\% 20$ of $\% 20$ Wales $\% 20$ \%E2\%80\%93\%20Final\%20report.pdf, 2019.

[50] F. Dembski, U. Wössner, M. Letzgus, M. Ruddat, C.. Yamu, "Urban digital twins for smart cities and citizens: the case study of Herrenberg, Germany", Sustainability, $12(2020)$.

[51] P. Verschuren, and R. Hartog, "Evaluation in designoriented research", Quality and Quantity, 39 (2005), pp. 733-762.

[52] Y. Wautelet, S. Heng, M. Kolp, and I. Mirbel, "Unifying and extending user story models", In International Conference on Advanced Information Systems Engineering. Springer, Cham, (2014), pp. 211-225.

[53] V. Braun, and V. Clarke, "Thematic analysis. APA Handbook of Research Methods in Psychology", (2) 2012, pp. 57-71.

[54] G.I. Susman, and R. D. Evered, "An assessment of the scientific merits of action research", Administrative science quarterly, (1978), pp. 582-60.

[55] I. Vilajosana, J. Llosa, B. Martinez, M. Domingo-Prieto, A. Angles, and X. Vilajosana, "Bootstrapping smart cities through a self-sustainable model based on big data flows", IEEE Communications magazine, 51 (2013), pp. $128-134$ 